SAKAI SAMBAYAN — Jurnal Pengabdian kepada Masyarakat

\title{
AUGMENTED REALITY PADA APLIKASI CINTABAHARI SEBAGAI MEDIA PROMOSI PULAU PAHAWANG
}

\author{
Mardiana*, Meizano Ardhi Muhammad, Yessi Mulyani, Wahyu Eko Sulistiono
}

\author{
Program Studi Teknik Informatika Universitas Lampung \\ Jl. Prof. Sumantri Brojonegoro No.1 Bandar Lampung 35145 \\ Penulis Korespodensi : mardiana@eng.unila.ac.id
}

\begin{abstract}
Abstrak
Kelompok Sadar Wisata (Pokdarwis) Cinta Bahari dibentuk oleh aparat Desa Pulau Pahawang Lampung sejak tahun 2013. Akan tetapi rendahnya tingkat pendidikan anggota Pokdarwis membuat mereka sangat sulit untuk dapat mengembangkan potensi wisata pulau Pahawang. Pada tahun 2017, promosi wisata sudah dilakukan menggunakan Teknologi Informasi dan Komunikasi (TIK) dalam bentuk mobile application CintaBahari yang dikembangkan pada kegiatan Pengabdian Kepada Masyarakat (PKM) sebelumnya. Namun demikian masalah promosi ini masih harus terus ditingkatkan dan berkelanjutan, sehingga jumlah kunjungan wisatawan yang diperoleh dapat lebih maksimal. Solusi yang ditawarkan oleh Tim PKM ini adalah mengembangkan media promosi dengan menggunakan teknologi Augmented Reality (AR) yang menggambarkan objek wisata Pahawang secara real yang dikemas secara menarik dan atraktif. Teknologi AR dapat menggabungkan benda maya dua dimensi atau tiga dimensi ke dalam sebuah lingkungan nyata tiga dimensi lalu memproyeksikan benda-benda maya tersebut dalam waktu nyata. Selain itu, Tim PKM ini juga memberikan sosialisasi tentang penggunaan aplikasi AR tersebut dan pembagian poster dengan konten AR kepada masyarakat sebagai sarana mereka memberikan promosi kepada wisatawan yang datang. Metoda yang digunakan dalam pembangunan aplikasi menggunakan metode iterative development yang disebut dengan Rapid Application Development (RAD) dengan tahapan : identifikasi masalah dan motivasi, menetapkan objek solusi, penerapan solusi dan pelatihan serta pelaporan hasil dan publikasi. Adanya aplikasi AR ini diharapkan dapat membuat peningkatan potensi wisatawan yang datang dan kembali datang lagi ke Pulau Pahawang melalui ketersediaan informasi yang lengkap dan menarik dalam bentuk AR. Sehingga secara langsung akan berdampak pada peningkatan pendapatan pokdarwis dan masyarakat Desa Pulau Pahawang pada umumnya.
\end{abstract}

Kata kunci: Augmented Reality, Cinta Bahari, Pokdarwis, Pahawang, Promosi

\section{Pendahuluan}

Saat ini semakin berkembanglah perumahan penduduk menjadi pemberhentian sementara, pemondokkan bagi wisatawan yang datang untuk menginap dengan lama tinggal 1 sampai 2 hari. Berdasarkan kondisi tersebut, maka pada tahun 2017 Tim PKM Unila kembali mengadakan Kegiatan Pengabdian Kepada Masyarakat untuk membina Kelompok Sadar Wisata (Pokdarwis) Cinta Bahari dengan membuat aplikasi mobile CintaBahari sebagai sarana promosi wisata di Pulau Pahawang (Mardiana, 2017).

Pokdarwis Cinta Bahari ini sebenarnya bukan satu-satunya Pokdarwis yang terdapat di Pulau pahawang, namun terdapat beberapa Pokdarwis lain (swasta), namun tidak berada di bawah koordinasi/binaan aparat desa (Setyawan, 2015). Pokdarwis Cinta Bahari terdiri dari 30 Orang anggota yang berasal dari dua pulau yang berbeda yaitu Pulau Pahawang Besar dan Pulau Pahawang Kecil. Kepengurusan Pokdarwis ini terdiri dari Pembina, Penasehat, Pimpinan, Sekretariat, Anggota, dan seksi-seksi (antara lain: Keamanan dan Ketertiban, Kebersihan dan Keindahan, Daya Tarik Wisata dan Kenangan, Hubungan Masyarakat dan Pengembangan Sumber Daya Manusia, Pengembangan Usaha) yang mempunyai profesi yang berbeda. Beberapa orang bergabung dalam satu kelompok wisata mempunyai profesi sebagai penyedia kapal, pemandu wisata, pengusaha jasa penyedia penginapan (home stay) dan kuliner.

Selama ini upaya Pokdarwis CintaBahari dalam meningkatkan jumlah kunjungan wisatawan ke Pahawang, masih sangat kurang jika dibandingkan upaya agen agen travel yang sebagian besar berasal dari luar Pahawang, bahkan dari luar Lampung. Kurangnya pengetahuan 
anggota Pokdarwis akan cara melakukan promosi dan memanfaatkan teknologi informasi menjadi kendalanya. Dengan adanya aplikasi mobile CintaBahari, Pokdarwis menjadi memiliki sarana promosi wisata Pahawang. Mereka dapat melakukan penyebaran informasi dan promosi dengan lebih luas mengenai kegiatan yang ada di Pahawang.

Berdasarkan data pada akhir tahun 2017 yang bersumber dari Dinas Pariwisata Kab. Pesawaran, Lampung dan data dari Pokdarwis CintaBahari, jumlah kunjungan wisata ke pulau Pahawang rata-rata mengalami peningkatan setiap bulannya seperti yang terlihat pada gambar 1. Dari data tersebut, rata-rata kunjungan yang menggunakan jasa Pokdarwis CintaBahari adalah sebanyak $20 \%-25 \%$. Salah satu faktor terjadinya peningkatan ini adalah semakin banyaknya promosi yang sudah dilakukan oleh Pokdarwis menggunakan aplikasi mobile. Dampak peningkatan kunjungan tersebut tentu saja berimbas pada omzet yang diperoleh Pokdarwis CintaBahari.

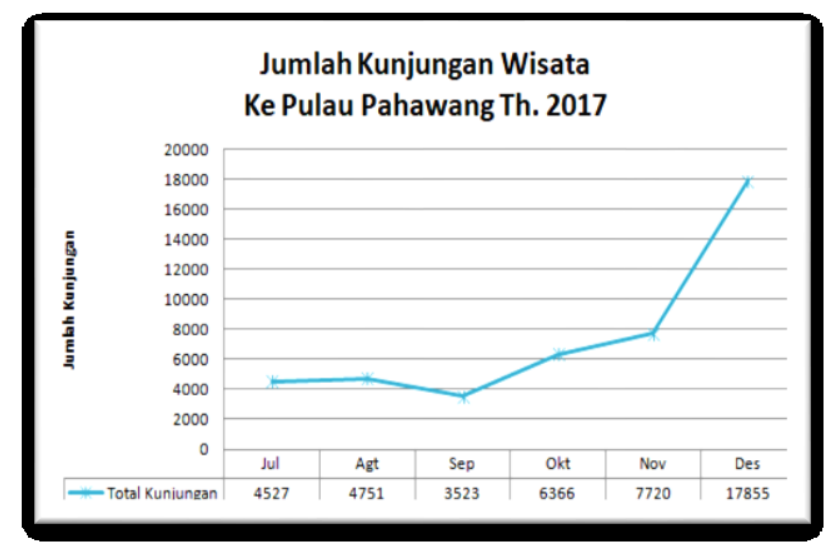

Gambar 1. Grafik Jumlah Kunjungan Wisatawan Tahun 2017

Namun demikian, berdasarkan informasi yang diperoleh pada kegiatan evaluasi kegiatan PKM dengan mitra Pokdarwis CintaBahari, masih harus menambahkan beberapa fitur yang lebih menarik sperti misalnya menerapkan Augmented Reality agar wisatawan memperoleh informasi mengenai objek wisata Pahawang dan dapat melihatnya dalam bentuk tiga dimensi secara real time. Selain itu pencarian lokasi wisata dapat dilakukan dengan memanfaatkan GPS dan kamera. Sehingga berdasarkan hasil evaluasi tersebut, kegiatan PKM ini adalah pengembangan fitur selanjutnya yang dibutuhkan pada aplikasi mobile CintaBahari yaitu dengan menerapkan Augmented Reality (AR).

Teknologi AR adalah teknologi yang menggabungkan benda maya 2 dimensi dan ataupun 3 dimensi ke dalam realitas (lingkungan nyata). Tidak seperti realitas maya yang sepenuhnya menggantikan kenyataan, AR sekedar menambahkan atau melengkapi kenyataan. AR bertujuan untuk mengembangkan teknologi yang melakukan penggabungan secara real-time digital content yang dibuat oleh komputer dengan dunia nyata (Haller, 2007).

Saat ini teknologi AR telah berkembang pesat di Indonesia seiring dengan banyaknya aplikasi-aplikasi pendukung yang banyak terdapat pada ranah e-commerce dan marketplace. Dikalangan anak muda sebagian besar familiar dengan aplikasi augmented reality seperti : Marvel AR, Star Wars Augmented Reality App , dan Google Translate Augmented Reality (Arie, 2016). Saat ini pemanfaatannya AR pada bidang pariwisata sudah semakin marak.

Keberadaan aplikasi AR yang dibangun tentu saja tidak boleh terlepas dari adanya pemeliharaan dan pemutakhiran konten (isi) nya dan pentingnya mempromosikan secara verbal dan non verbal (Effendy, 2006). Dengan demikian kegiatan pendampingan mitra sasaran berupa pelatihan dan kerja praktek harus dilakukan agar terbangun kemampuan dan ketrampilan dan yang menunjang strategi promosi (Alifahmi, 2005). Pendampingan mitra Pokdarwis CintaBahari tersebut juga dilakukan pada kegiatan PKM ini.

\section{A. Permasalahan Mitra}

Berdasarkan evaluasi kegiatan Tim PKM Unila sebelumnya, permasalahan yang dimiliki mitra yaitu Pokdarwis Cinta Bahari Pulau Pahawang adalah sebagai berikut:

1. Pokdarwis belum memiliki aplikasi AR yang dapat digunakan konsumen untuk memperoleh informasi mengenai objek wisata Pahawang lebih menarik dan atraktif dan dapat dilihat dalam bentuk tiga dimensi secara real time. Selain itu pencarian lokasi wisata dapat dilakukan dengan memanfaatkan GPS dan kamera.

2. Pokdarwis belum memiliki poster dengan konten marker AR yang dapat dijadikan sarana promosi bagi wisatawan yang berkunjung. 
B. Kerangka Pemecahan Masalah

Kerangka pemecahan masalah secara sistematis dapat digambarkan dalam bentuk diagram gambar 2 berikut:

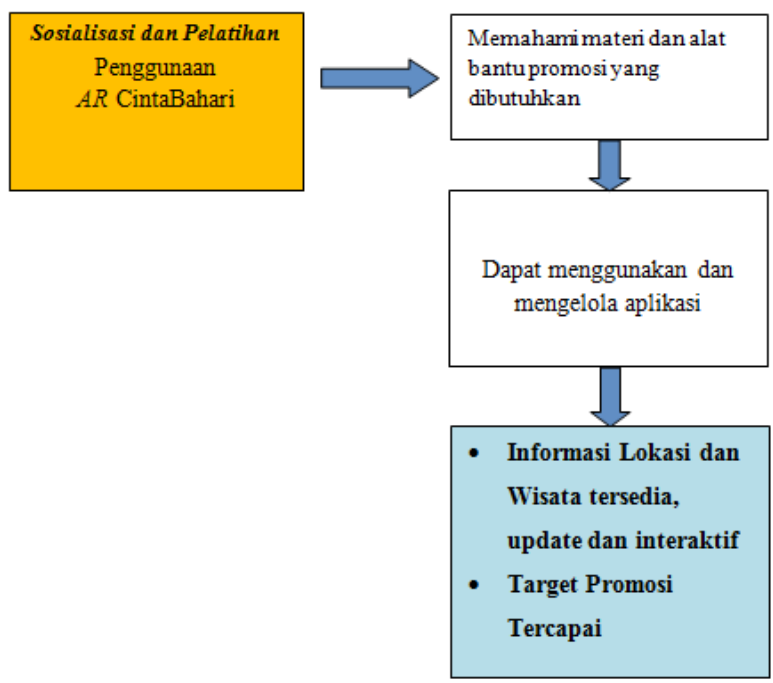

Gambar 2. Kerangka Pemecahan Masalah

\section{Metode Pendekatan dan Tahapan Pelaksanaan}

Metoda yang digunakan dalam pembangunan perangkat lunak menggunakan metode iterative development yang disebut dengan Rapid Application Development (RAD) yang menggunakan perangkat CASE (Computer Aided Software Engineering) (Pressman, 2010). Bagan alir tahapan dapat dilihat pada gambar 3 berikut :

REQUIREMENTS PLANNING

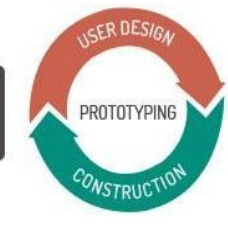

Gambar 3. Metode Pengembangan Solusi RAD

Tahapan metode RAD dalam keseluruhan pelaksanaan kegiatan ini adalah :

1. Tahapan identifikasi masalah dan motivasi

2. Menetapkan objek solusi

3. Melaksanakan tahapan RAD

4. Pelaporan hasil penelitian

\section{A. Partisipasi mitra}

Partisipasi mitra pada tahap persiapan dalam hal ini ketua Pokdarwis memfasilitasi kebutuhan tim PKM Unila terkait dengan identifikasi masalah dan solusi yang dibutuhkan, pengurusan ijin, penyiapan sarana kegiatan yang ada di pulau Pahawang dan penyiapan tenaga pendamping. Pada tahap pembuatan program aplikasi AR, peran mitra adalah memberi masukan dan feedback pada setiap tahap metoda RAD yng digunakan. Pada tahap pelaksanaan, tim Pokdarwis berperan aktif mengikuti sosialisasi dan praktek langsung cara menggunakan aplikasi dan alat bantu poster. Kemudian, pada tahap evaluasi pelaksanaan kegiatan mitra berpartisipasi dalam menyampaikan data hasil promosi dan transaksi yang dilakukan.

\section{B. Rancangan Evaluasi}

Secara garis besar evaluasi kegiatan dilakukan dalam tiga bentuk, yaitu evaluasi awal, evaluasi proses, dan evaluasi akhir kegiatan. Evaluasi awal dilakukan di awal kegiatan, dengan maksud untuk memperoleh gambaran lengkap mengenai pemahaman Pokdarwis. Evaluasi proses akan dilakukan pada tahap pembuatan program aplikasi. Evaluasi ini dilakukan untuk mengetahui persepsi calon pengguna terhadap aplikasi yang dikembangkan. Sebagai indikator keberhasilan adalah adanya aplikasi AR beserta poster konten promosi yang siap dipublikasikan. Evaluasi akhir kegiatan dilakukan pada akhir program kegiatan, dengan maksud untuk mengetahui besarnya peningkatan pengetahuan dan pemahaman yang berhasil dicapai.

\section{Hasil dan Pembahasan}

\section{A. Pembuatan Program aplikasi mobile}

\section{Pengumpulan Kebutuhan}

Tahapan pengumpulan kebutuhan adalah mengumpulkan seluruh data lokasi yang akan digunakan pada aplikasi. Berikutnya, untuk masing-masing lokasi tersebut dibuatkan marker. Lokasi diambil berdasarkan kategori yaitu dermaga, homestay, cottage dan spot snorkling dan pantai. Contoh dari penentuan lokasi dan marker yang akan digunakan pada aplikasi AR CintaBahari, terdapat pada tabel 1 berikut. 
Tabel 1. Lokasi dan Marker

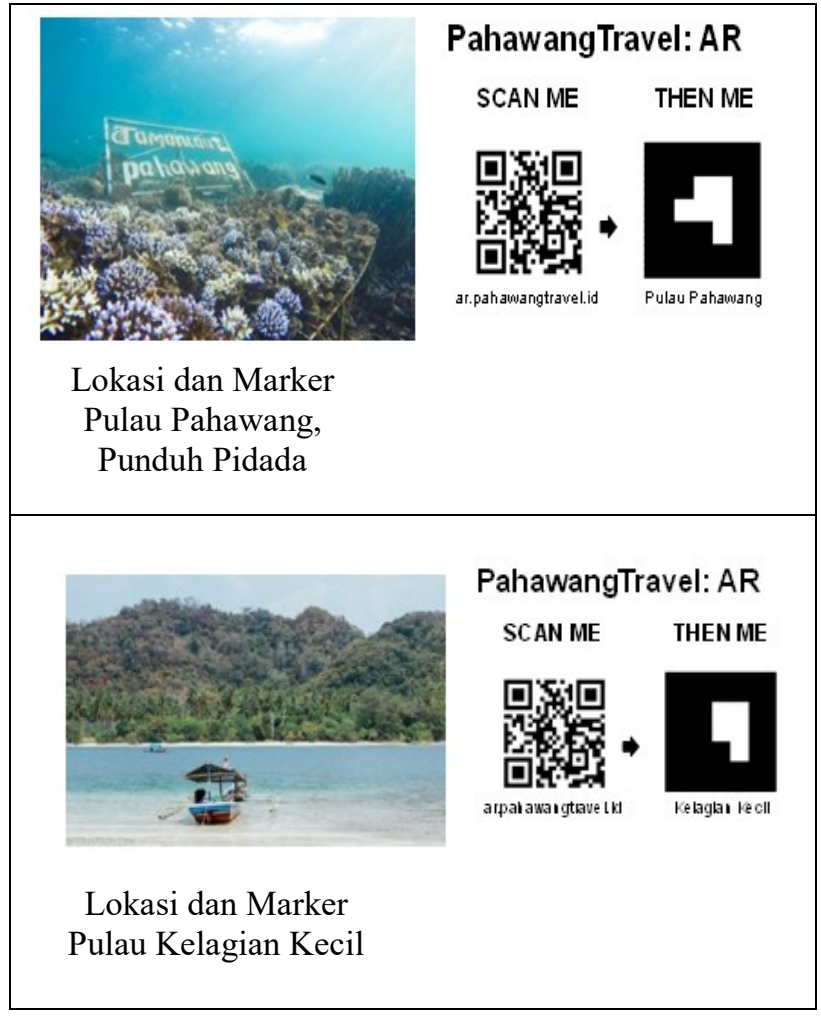

\section{Fitur dan Tampilan Produk}

Aplikasi Cinta Bahari AR ini diakses dengan menggunakan website atau mobile menggunakan smartphone. Mengakses aplikasi dengan mengetikan alamat Website pahawangtravel.id pada browser pada mobile seperti pada gambar 4 .

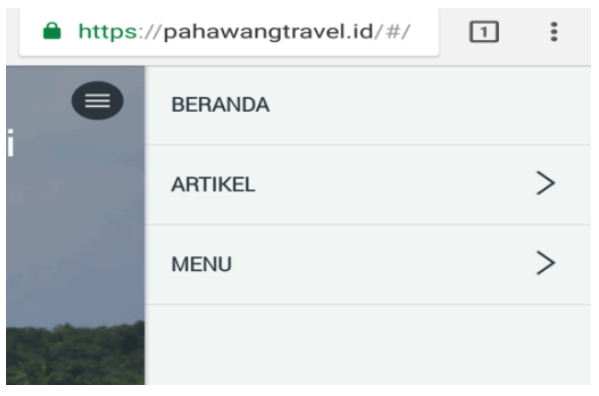

Gambar 4. Menu Website Pada Media Mobile

Pada aplikasi, disertakan mode AR untuk mendapatkan informasi menggunakan kamera yang men-scan Qrcode untuk mendapatkan informasi dalam bentuk gambar dan teks. Pada aplikasi, tersedia tombol AR untuk menggunakan mode AR. Saat tombol diklik oleh user akan memanggil event handler onclicklistener pada aplikasi yang meneruskan pada browser default pada smartphone dengan menggunakan external intent yang meneruskan link web ar.pahawangtravel.id.

Saat website berhasil diakses atau diload, browser default akan meminta untuk menggunakan kamera untuk men-scan Qrcode yang tersedia untuk mendapatkan informasi mengenai pahawang.

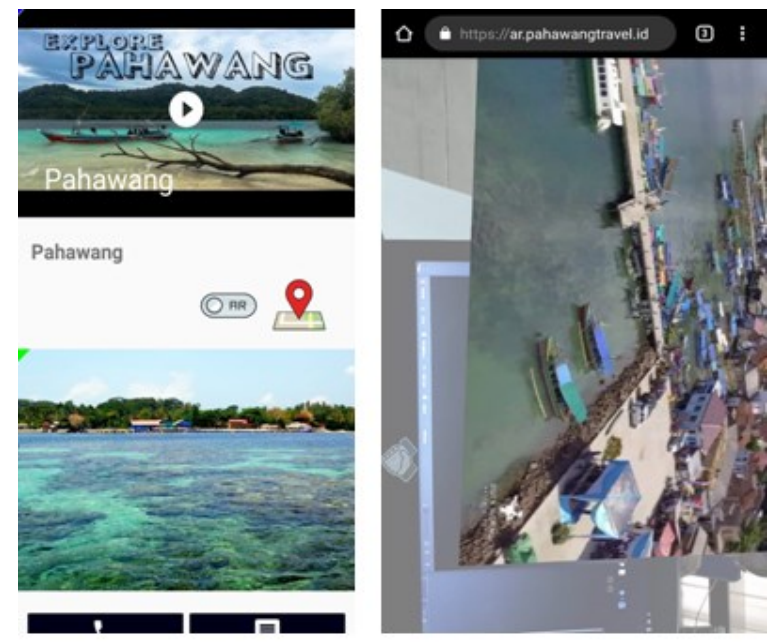

Gambar 5. Mode AR pada aplikasi Cinta Bahari

3. Pengujian Aplikasi AR

Tabel 2. Hasil Pengujian Black Box

\begin{tabular}{|c|c|c|}
\hline Halaman & Yang Diuji & Hasil \\
\hline \multirow{3}{*}{$\begin{array}{l}\text { Menu } \\
\text { Utama }\end{array}$} & Tombol AR camera & Berhasil Dengan Baik \\
\hline & Tombol Informasi & Berhasil Dengan Baik \\
\hline & Tombol Exit & Berhasil Dengan Baik \\
\hline $\begin{array}{l}\text { Menu AR } \\
\text { Camera }\end{array}$ & $\begin{array}{l}\text { AR Camera terhadap } \\
\text { Marker }\end{array}$ & Berhasil Dengan Baik \\
\hline \multirow{9}{*}{$\begin{array}{l}\text { Menu } \\
\text { Informasi } \\
\text { Lokasi }\end{array}$} & Pulau Pahawang & Berhasil Dengan Baik \\
\hline & Dermaga Ketapang & Berhasil Dengan Baik \\
\hline & Homestay & Berhasil Dengan Baik \\
\hline & Cottage & Berhasil Dengan Baik \\
\hline & Taman Nemo & Berhasil Dengan Baik \\
\hline & Gosong Bekri & Berhasil Dengan Baik \\
\hline & Gosong Pancong & Berhasil Dengan Baik \\
\hline & Cukuh Bendil & Berhasil Dengan Baik \\
\hline & Kelagian Kecil & Berhasil Dengan Baik \\
\hline
\end{tabular}

Berdasarkan pengujian Black Box yang telah dilakukan diperoleh hasil yang ditunjukan pada tabel 2 tersebut. Semua menu pada Menu utama meliputi tombol AR Camera, tombol Informasi Lokasi berjalan dengan baik.

\section{B. Kegiatan FGD dan Sosialisasi Aplikasi AR Cinta Bahari \\ Kegiatan FGD Pertemuan Pengembang Aplikasi dan Sosialisasi Aplikasi AR CintaBahari dilakukan di Universitas Lampung seperti yang}


terdapat pada gambar 6. Pada kegiatan sosialisasi para peserta mendapatkan materi penggunaan aplikasi CintaBahari dan diminta untuk memberikan tanggapan dan persepsi mengenai aplikasi yang dibuat.
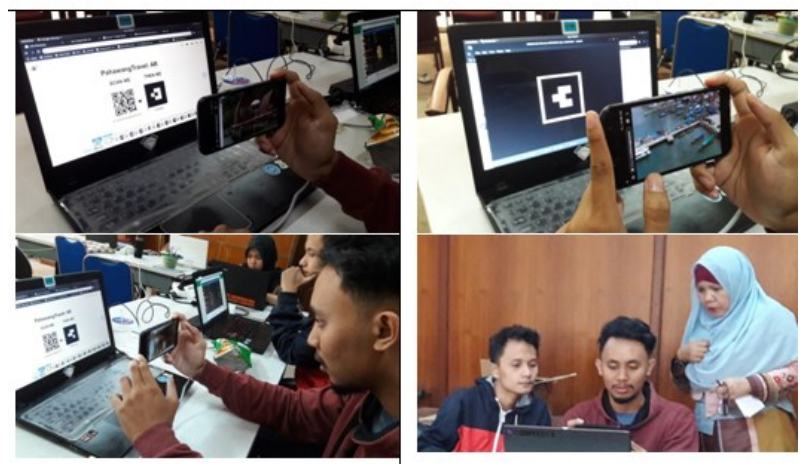

Gambar 6. FGD Pertemuan Pengembang Aplikasi dan Sosialisasi

Persepsi pengguna terhadap aplikasi dinilai menggunakan kuisioner yang berisi pendapat dan pengalaman terhadap aplikasi, seperti yang terdapat pada tabel 3. kuisioner. Penilaian dilakukan terhadap 9 responden yang merupakan masyarakat umum dengan domisili di luar Pulau Pahawang. Dalam analisis kuisioner ini, setiap jawaban mempunyai nilai masing masing sebagai berikut :

STS $=$ Sangat Tidak Setuju, Nilai $=1$

$\mathrm{TS}=$ Tidak Setuju, Nilai $=2$

$\mathrm{N}=$ Netral, Nilai $=3$

$\mathrm{S}=$ Setuju, Nilai $=4$

$\mathrm{SS}=$ Sangat Setuju, Nilai $=5$
Tabel 3. Kuisioner

\begin{tabular}{|c|c|c|c|c|c|c|c|}
\hline \multirow[t]{2}{*}{$\mathrm{N}_{0}$} & \multirow[t]{2}{*}{ Pertanyaan } & \multicolumn{5}{|c|}{ Jawaban } & \multirow[b]{2}{*}{$\begin{array}{c}\% \text { persepsi } \\
\text { S dan SS }\end{array}$} \\
\hline & & STS & TS & N & S & SS & \\
\hline 1. & $\begin{array}{l}\text { Semua fungsi aplikasi berjalan dengan } \\
\text { baik. }\end{array}$ & & & 3 & 3 & 3 & 67 \\
\hline 2. & Aplikasi mudah untuk digunakan. & & & 1 & 4 & 4 & 89 \\
\hline 3. & Tampilan aplikasi menarik bagi pengguna. & & & 1 & 5 & 3 & 89 \\
\hline 4. & $\begin{array}{l}\text { Dengan adanya aplikasi membanty } \\
\text { masyarakat awam mengenal objek wisata } \\
\text { di Pulau Pahawang. }\end{array}$ & & & 1 & 3 & 5 & 89 \\
\hline 5. & $\begin{array}{l}\text { Dengan adanya aplikasi dapat menarik } \\
\text { minat masyarakat mengunjungi objek } \\
\text { pariwisata di Pulau Pahawang. }\end{array}$ & & & 1 & 4 & 4 & 89 \\
\hline 6. & $\begin{array}{l}\text { Objek wisata, lokasi dan foto dalam } \\
\text { aplikasi ini cukup mewakili objek } \\
\text { pariwisata di Pulau Pahawang. }\end{array}$ & & & & 6 & 3 & 100 \\
\hline 7. & $\begin{array}{l}\text { Aplikasi ini layak untuk digunakan dan } \\
\text { disebarluaskan ke masyarakat. }\end{array}$ & & & 1 & 2 & 6 & 89 \\
\hline
\end{tabular}

Dari hasil kuisioner tersebut dapat disimpulkan bahwa persepsi positif pengguna terhadap aplikasi yang ditandai dengan nilai setuju (s) dan sangat setuju (ss) secara keseluruhan minimal $69 \%$ dan maksimal $100 \%$.

\section{Monitoring dan Evaluasi}

Setelah kegiatan sosialisasi penggunaan aplikasi CintaBahari, tim Pokdarwis dimonitoring dan dievaluasi perkembangannya. Pada kegiatan ini, tim kembali melakukan sosialisasi dan pemberian poster promosi kepada pokdarwis dan warga. Poster yang memanfaatkan teknologi AR tersebut akan digunakan pokdarwis dan warga untuk promosi kepada pengunjung atau wisatawan. Tampilan poster seperti pada gambar 7 .
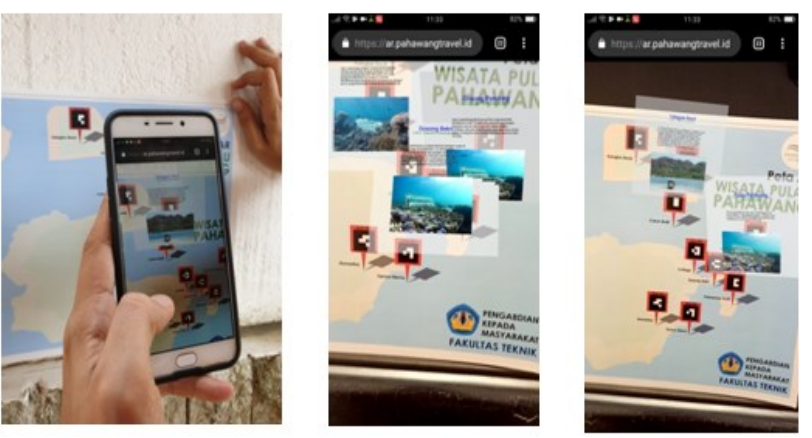

Gambar 7. Poster teknologi AR

Pada kesempatan ini juga warga diberi poster dan dihimbau untuk menempelkan poster pada rumah atau tempat yang strategis di pulau Pahawang, seperti pada gambar 8 . 


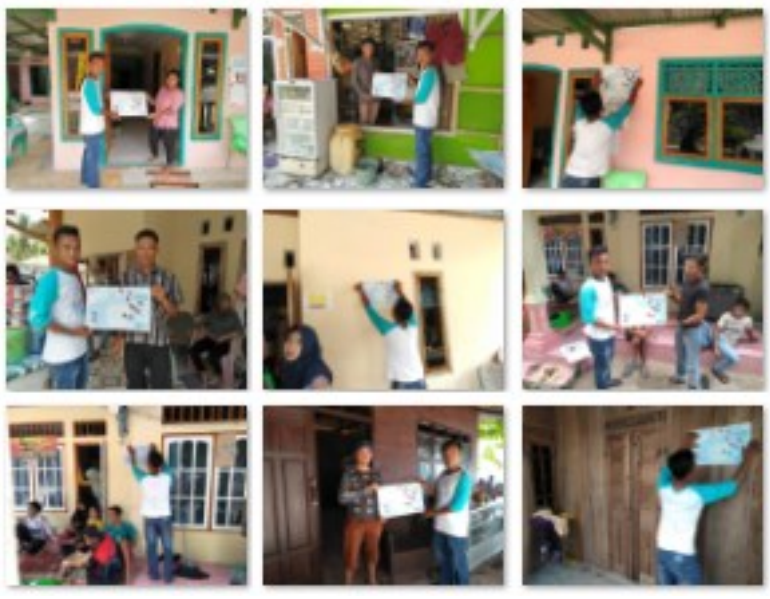

Gambar 8. Poster diberikan kepada warga

Dari hasil evaluasi dan komunikasi yang dilakukan, diketahui bahwa penggunaan aplikasi mobile sebagai sarana promosi telah mereka lakukan walaupun masih belum sempurna. Hal ini menandakan adanya peningkatan pemahaman pokdarwis akan alat bantu aplikasi tersebut dalam aktifitas mereka. Namun untuk data terkait capaian berupa peningkatan omzet pokdarwis belum dapat diperoleh, mengingat data yang terkumpul masih sangat sedikit. Diharapkan dengan berjalannya waktu akan dapat diketahui adanya capaian untuk hal tersebut.

\section{Kesimpulan}

Berdasarkan pembahasan yang telah diuraikan pada bab-bab sebelumnya, maka hasil kegiatan PKM ini dapat dirumuskan sebagai berikut :

1. Pengembangan aplikasi CintaBahari AR dapat dilakukan dengan baik. Berdasarkan pengujian menggunakan metode Black Box diperoleh kesimpulan bahwa aplikasi ini dapat beroperasi pada perangkat Smartphone Android dengan menampilkan informasi dan visualisasi AR tentang 9 objek wisata di Pulau Pahawang.

2. Persepsi user terhadap aplikasi yang diperoleh dengan menggunakan kuisioner adalah menunjukan bahwa aplikasi ini mudah digunakan dan menarik minat masyarakat dengan persepsi positif pada setiap pertanyaan, ditandai dengan nilai setuju (s) dan sangat setuju (ss) secara keseluruhan minimal $69 \%$ dan maksimal $100 \%$.

3. Setelah mengikuti sosialisasi, peserta dapat menggunakan aplikasi mobile CintaBahari yang dilengkapi dengan poster promosi yang memanfaatkan teknologi AR, sehingga tampilan dapat lebih menarik dan informatif.

\section{Daftar Pustaka}

Alifahmi, H. 2005. Sinergi Komunikasi Pemasaran: Integrasi Iklan, $P R$, dan Promosi. Jakarta: Quantum.

Arie, A. S., et. al , 2016, Pengembangan Bisnis Model Virtual Reality \& Augmented Reality Platform di Bidang E-Commerce, Thesis Pasca Sarjana, Manajemen, Binus Jakarta

Effendy, Onong Uchjana. 2006. Ilmu Komunikasi Teori dan Praktek, PT. Remaja Rosdakarya. Bandung.

Haller, Billinghurst, Thomas, 2007, Emerging Technologies of Augmented Reality : Interfaces and Design, Idea Group.

Mardiana, Muhammad, M.A., Wijaya, T., 2017, Mobile Application CintaBahari Sebagai Sarana Promosi Pokdarwis Pulau Pahawang Lampung, Jurnal Nasional, Sakai Sambayan Vol 1 No 3, pp. 96-103, 2017. ISSN 2550-1089

Pressman, R. S. 2010. Software Engineering : A practitioner's Approach. Seventh Edition. New York: McGraw-Hill.

Setyawan, A. 2015. Warga Pulau Pahawang Serius Kembangkan Wisata Bahari. Antara Lampung.com, http://lampung.antaranews.com/berita/28509 1/warga-pulau-pahawang-seriuskembangkan-wisata-bahari (akses Mei 2015). 